\title{
Catatan Kuliah Ekonomi, Bisnis, Regulasi dan Kebijakan Telekomunikasi Bab 2 semester 2 Tahun 2017/2018: Prinsip- Prinsip Ilmu Hukum.
}

\author{
Sigit Haryadi \\ Institut Teknologi Bandung
}

Januari 2018

Paper DOI: $10.17605 /$ OSF.IO/CFHS4

Citation: Haryadi, S. (2018, January 19). Catatan Kuliah Ekonomi, Bisnis, Regulasi dan Kebijakan Telekomunikasi Bab 2 semester 2 Tahun 2017/2018: Prinsip-Prinsip IImu Hukum. Retrieved from osf.io/3c9n4

\subsection{Perlunya Engineer Belajar Prinsip-prinsip Ilmu Hukum}

a) Norma - norma hukum yang berlaku di suatu Negara adalah wajib dipatuhi oleh setiap warga Negara, dan tidak boleh ada seorang warganegara yang menolak mematuhi suatu norma hukum dengan alasan tidak mengetahui adanya suatu peraturan perundangan yang telah dilanggarnya.

b) Seorang engineer dalam rangka merancang suatu perangkat keras maupun perangkat lunak harus mengetahui dan menyatakan dasar hukum dan referensi teknis yang menjadi landasan bagi rancangannya.

c) Sayangnya, di Indonesia terjadi kekeliruan dalam memaknai ilmu hukum, yang dikira hanya sekedar hapalan, padahal ilmu hukum (legal science) yang benar hanya bisa dipelajari oleh orang-orang yang memiliki kecerdasan penalaran dan logika.

\subsection{Konsep Norma Hukum}

$\checkmark$ Hukum adalah agregasi atau sistem dari norma-norma

$\checkmark$ Kata "Norm" dalam bahasa-bahasa Barat, berasal dari bahasa Latin "norma", yang kebetulan juga digunakan dalam bahasa Indonesia

$\checkmark$ Menurut filsafat hukum:

i. Norma hukum adalah preskripsi (resep) bagi tingkah laku timbal balik antar manusia

ii. Norma mempunyai makna ketertiban dan atau perintah

iii. Fungsi norma adalah untuk memberikan perintah, memberikan kewenangan (authorising), memberikan ijin dan menderogasi 


\subsection{Inti studi ilmu hukum}

Inti studi ilmu hukum adalah logika

$>$ "logika" sebagai suatu cabang keilmuan menjadi pokok ilmu (subject matter) dari ilmu hukum, karena ilmu hukum memerlukan usaha memaparkan, menggambarkan, menetapkan (posits) norma-norma. Logika juga diperlukan untuk membuat preskripsi dan penentuan (ordain) suatu cara berpikir tertentu

$>$ Ilmu hukum juga mempelajari validitas suatu norma berdasar hubungan antara segala sesuatu yang"harus" terjadi dengan sesuatu yang"biasa" terjadi. Juga memutuskan apakah suatu norma sebagai suatu "kewajiban" (duty) atau sekedar "kebiasaan" (to be accustomed) atau bersifat keduanya

\subsection{Hukum Positif vs Hukum Normatif}

$\checkmark$ Hukum Positif adalah agregasi atau sistem dari norma-norma yang PADA KENYATAANNYA diberlakukan di suatu waktu dan tempat tertentu

$\checkmark$ Hukum Normatif adalah agregasi atau sistem dari norma-norma yang SEHARUSNYA (berdasar etika dan nilai) diberlakukan di suatu waktu dan tempat tertentu

\subsection{Ilmu hukum untuk orang-orang yang mempunyai kecenderungan religius}

- Orang-orang yang religius mempunyai perhatian khusus pada hal yang dipandang sebagai "baik" dan "buruk", dimana segala hal yang diyakininya sebagai "menuruti perintah Tuhan" adalah "baik" dan yang segala yang "melanggar perintah Tuhan" adalah "buruk" dengan demikian orang-orang yang religious senantiasa berusaha agar norma hukum di negaranya disusun dengan mengacu prinsip - prinsip agama yang dianutnya.

- Ilmu hukum untuk orang-orang yang mempunyai kecenderungan relegius adalah bersifat khusus, karena"KEWAJIBAN" hampir selalu berarti"KEBIASAAN" padahal norma hukum yang berlaku di negaranya membedakan "kewajiban"vs "kebiasaan

- Tetapi dalam prakteknya sering terjadi penyimpangan pada pernyataan di atas, contohnya:

- Tahun 1992: di suatu county yang bernama Sonoma County di California - USA, akan memberlakukan semacam Perda yang mewajibkan anak sekolah untuk berdoa sebelum dan sesudah pelajaran sekolah dimulai, ternyata usulan tersbut ditolak oleh warga setempat, padahal orang - orang USA mengaku sebagai orang- orang religious sebagaimana tertulis di uang kertasnya "in God we Trust".

- Terjadi pertentangan keras di Indonesia saat beberapa tahun lalu akan disusun UU Anti Pornografi dan adanya usaha-usaha belakangan ini untuk melegalkan LGBT.

\subsection{Beda Penyamun dan Hakim}

$>$ Seorang hakim yang memutuskan agar seorang penjahat dihukum penjara, memiliki makna subyektif "memerintahkan" agar penjahat dimasukkan ke penjara 
$>$ Seorang penyamun di jalan raya yang memerintahkan sesorang untuk menyerahkan uang kepadanya , makna subyektifnya adalah suatu tindakan "memerintah" (act of command)

$>$ Beda antara perintah seorang penyamun dengan norma sebuah badan resmi (legal organ): Setiap makna subyektif juga mengandung makna obyektif, dengan demikian suatu tindakan memerintah secara obyektif dapat dijadikan suatu norma yang mengikat, bila tindakan itu mendapat kewenangan (authorised)

- Penjahat yang dihukum oleh pengadilan harus tunduk, karena itu merupakan perintah yang sah (lawful command) dari suatu badan administratif atau badan yudisial.

- Jika seseorang tidak tunduk pada perintah penyamun, dia tidak melanggar norma dengan demikian dia tidak mempunyai kewajiban untuk mematuhi.

$>$ Persoalan ini bisa juga terjadi pada bidang telekomunikasi, sebagai contohnya dimana tindakan negara yang memerintahkan operator telekomunikasi, untuk membayar BHP Spektrum frekreunsi adalah merupakan tindakan memerintah secara obyektif yang merupakan suatu norma yang mengikat, karena negara mempunyai kewenangan (authorized) sesuai regulasi yang sah berlaku. Tetapi jika terdapat oknum pegawai negara yang memerintahkan operator telekomunikasi untuk membayar segala sesuatu yang tidak diatur dalam regulasi yang sah, maka operator dalam hal ini tidak mempunyai kewajiban untuk mematuhi, karena tindakan oknum ini tidak beda dengan seorang penyamun.

\subsection{Law applying Organ}

$>$ "law applying organ" adalah badan resmi yang berpegang pada norma-norma yang disusun oleh legislator dan sangat penting bahwa legislator seharusnya berisi orang-orang yang mempunyai keahlian dan integritas. Contoh di Indonesia untuk menangani pelanggaran terhadap norma hukum Telekomunikasi yang berlaku, maka sebelum dilimpahkan ke pengadilan, penyelidikan dan penyidikan bisa dilakukan oleh kejaksaan dan juga oleh pejabat sipil non-kejaksaan yang mendapat otorisasi untuk ini.

$>$ Di negara-negara yang tata hukumnya masih lemah, sering terdapat law applying organ yang merangkap sebagai legislator, misalnya departemen-departemen yang mengeluarkan berbagai peraturan dan keputusan yang akan mereka laksanakan sendiri, dimana problem seperti ini, umumnya disebabkan oleh legislator "resmi" tidak mampu bekerja secara efektif, yang menyebabkan penyusunan kitab undang-undang beserta berbagai amandemennya selalu membutuhkan waktu lama dan dana besar. Khusus di Indonesia, beberapa tahun belakangan sudah mulai dilakukan penertiban terhadap peraturan lembaga negara atau kementerian yang dapat dikategorikan sebagai Norma yang sah berlaku.

\subsection{Beda Kitab Undang-Undang dan Buku Teks}

$\checkmark$ Suatu kalimat yang terdapat di dalam Kitab Undang-Undang harus mempunyai satu makna, tetapi Kalimat dalam buku teks bisa mempunyai banyak makna.

- Kalimat dalam Kitab Undang-Undang bermakna suatu perintah (decreed)

- kalimat dalam buku teks bermakna deskriptif, karena pengarang buku teks tidak berkompetensi untuk memerintahkan suatu apapun

$\checkmark$ Contoh: kalimat "Koruptor-koruptor SEHARUSNYA dihukum penjara", dimana Kata "seharusnya" dalam kalimat tersebut HARUS ADA dalam Kitab Undang-Undang karena mempunyai makna preskriptif, yang bermakna mungkin dipenjara, mungkin tidak, bila ada pasal-pasal yang mengatur tentang jenis-jenis hukuman selain hukuman penjara. Tetapi di 
dalam buku teks, kalimat tersebut boleh dituliskan sebagai berikut "penjahat-penjahat dihukum penjara" (tanpa dilengkapi kata "seharusnya"), dan tidak dinilai sebagai suatu kesalahan.

\subsection{Beda Ilmu Alam dan Ilmu Hukum}

D Realitas dari hukum alam adalah berdasar pada nilai " benar" dari hukum alam tersebut

> Realitas dari legal science berdasar nilai "sah" (= valid = berlaku) dari hukum tersebut

$>$ Realitas dari hukum alam pada umumnya adalah immanensi dari suatu keharusan (ought to) pada sesuatu yang sudah ada, misal hukum Newton tentang gravitasi, yang dinyatakan sebagai sesuatu yang "benar" setelah Newton menyatakannya dan membuktikannya, padahal realita sebenarnya dari hukum Newton adalah merupakan sesuatu yang sudah "benar" jauh sebelum Newton merumuskannya dan tetap "benar" sampai di masa yang akan dating yang relative lama, yaitu saat ada orang lain yang merumuskan kemungkinan terjadinya penyimpangan terhadapnya.

$>$ Di sisi lain, ilmu hukum adalah terdiri dari norma-norma yang dinilai sah atau valid apabila dia harus ditaati oleh masyarakat di suatu waktu dan tempat tertentu. Oleh karena sah atau tidaknya suatu norma hukum adalah tergantung ruang dan waktu, maka norma hukum tidak mungkin mempunyai nilai "benar" atau nilai "salah", karena segala sesuatu yang bernilai "benar" atau "salah" adalah tetap "benar atau "salah" dalam waktu yang "abadi" atau setidak-tidaknya "dalam jangka waktu sangat lama

\subsection{Jiwa dari Undang-Undang}

> Latar belakang dari pemberian kebijaksanaan yang bebas (free discretion) adalah karena lawapplying organ yang sedang menghadapi situasi yang rinciannya belum diatur dalam Kitab Undang-Undang. Di Indonesia contohnya, adalah ketika ada seorang hakim yang mendefiniskan "keperawanan"sebagai "barang berharga", ketika hakim tersebut menghukum seorang "penjual keperawanan gadis". Ini merupakan free discretion yang langka terjadi di Indonesia, padahal di Negara-negara maju, free discretion merupakan sesatu yang dinilai wajar. Namun saying, free discretion tadi, kemudian dibatalkan atas usaha beberapa ahli hukum yang memanfaatkan "keluguan"sekelompok orang awam yang menuntut bahwa "pernyataan keperawanan adalan barang berharga"adalah merupakan suatu penghinaan pada perempuan. Padahal tindakan hakim yang menyatakan hal itu menurutnya justru merupakan penghormatan kepada wanita.

$>$ Pada prinsipnya tata Hukum di semua negara di dunia memberi kewenangan kepada lawapplying organ untuk menerapkan norma-norma umum dari hukum khusus berdasar konsep analogi, seperti contoh di atas.

> Problem dari free discretion adalah akan muncul "suatu Hukum-hukum baru" di pengadilan karena keputusan dari beberapa beberapa hakim yang belum tentu sama. Di negara-negara yang belum maju, konflik antar "hukum-hukum baru" seperti ini masih akan muncul dan dianggap sebagai suatu yang normal dan wajar, karena memang sifat manusia yang tidak mungkin sempurna.

> Untuk mengatasi problem seperti ini, di setiap negara hendaknya terdapat suatu badan badan yang mempunyai kebijaksanaan yudisial (judicial discretion), yang bertugas membatasi kewenangan law applying organ dalam hal free discretion ini. 


\subsection{Imperatif (pernyataan) yang dapat menjadi norma}

Suatu imperatif (pernyataan) dapat menjadi suatu norma bila memenuhi syarat validasi, dan sebaliknya tidak bisa dinilai sebagai suatu norma, bila validitasnya telah diragukan atau dapat dibuktikan salah berdasar silogisme praktikal

\section{a.Contoh penerapan silogisme praktikal (1):}

- Soal: Apakah imperratif (atau pernyataan) sebagai berikut " semua manusia akan mati" adalah dapat dijadikan sebagai suatu norma?

- Jawab:

- Premis mayor adalah imperative yang sedang diuji: "Semua manusia akan mati"

- Premis minor untuk menguji harus digunakan suatu norma yang diakui adalah valid, misal "Socrates adalah seorang manusia"

- Kesimpulan dari dua premis tersebut akan memunculkan sutau imperative yang valid, yaitu: "Socrates akan mati"

- Maka: terbukti bahwa Imperatif "Semua manusia akan mati", DAPAT menjadi suatu norma, karena berdasar silogisme praktikal di atas, bisa dibuktikan bahwa telah memunculkan imperatif baru yang juga valid, yaitu "Socrates akan mati".

\section{b.Contoh penerapan silogisme praktikal (2):}

- Soal: Apakah imperratif (atau pernyataan) sebagai berikut "Cintailah musuh-musuh anda" akan dapat dijadikan sebagai suatu norma?

- Jawab:

- Premis mayor adalah imperative yang sedang diuji: "Cintailah musuh-musuh anda"

- Premis minor untuk menguji harus digunakan suatu norma yang diakui valid, misal "Setan adalah musuh manusia"

- Kesimpulan dari dua premis tersebut ternyata akan memunculkan suatu imperative yang tidak valid, yaitu: "Manusia harus mencintai setan"

- Maka: terbukti bahwa Imperatif "Cintailah musuh-musuh anda" TIDAK DAPAT menjadi suatu norma, karena telah memunculkan imperatif lain yang tidak valid, yaitu "Manusia harus mencintai setan"

Catatan: Di negara-negara yang kurang maju, sering sekali terdapat suatu imperatif (pernyataan) yang tidak valid tetap dijadikan sebagai suatu norma, karena telah dimanfaatkan oleh pihak-pihak tertentu untuk kepentingan mereka

Tugas: carilah suatu imperative di Indonesia yang telah menjadi norma hukum, lalu ujilah imperative tersebut saat belum menjadi norma hukum, menggunakan silogisme praktikal. Hasil pengujian boleh benar atau salah, terserah anda. 


\subsection{Konflik antar Norma}

Terdapat tiga jenis konflik antar norma

[1] Konflik yang niscaya tidak dapat dihindari karena bersifat total dan bilateral

- $\quad$ Misal: Norma 1: Cintailah musuh-musuh anda; Norma 2: Bencilah musuh-musuh anda; Maka mematuhi Norma 1 niscaya melanggar Norma 2 vice versa.

[2] Konflik yang mungkin dapat dihindari mungkin tidak dapat dihindari, karena merupakan konflik yang bersifat bilateral dan parsial

- Contoh: Norma 1: Semua manusia tidak boleh berbohong; Norma 2: Jika dengan tujuan menolong pasiennya, maka seorang dokter boleh berbohong; Dengan demikian mematuhi Norma 2 niscaya melanggar Norma 1, tetapi mematuhi Norma 1 belum tentu melanggar Norma 2 , dan hanya mungkin melanggar, yaitu ketika ada dokter berbohong kepada pasiennya

[3] Konflik yang mungkin dapat dihindari, karena bersifat parsial dan bersifat unilateral

- Contoh: Norma 1: Pembunuhan berencana yang dilakukan oleh pelaku berusia di atas 20 tahun harus dihukum mati; Norma 2: Pembunuhan berencana yang dilakukan oleh pelaku berusia di atas 18 tahun harus dihukum mati; Maka mematuhi Norma 1 tidak melanggar Norma 2, tetapi mematuhi Norma 2 melanggar Norma 1.

Tugas: Carilah contoh-contoh di bidang telekomunikasi di Indonesia, yang memiliki dua norma yang satu dan lainnya adalah: (a) bersifat konflik total dan bilateral, (b) bersifat bilateral dan parsial, dan (c) bersifat parsial dan unilateral

\subsection{Prinsip Derogasi (Amandemen)}

$>$ derogasi adalah salah satu fungsi norma, dimana derogasi menjadi ada jika terdapat suatu norma lain yang dinyatakan telah dibatalkan ke-absahannya

$>$ derogasi adalah memainkan peran penting dalam lingkungan tata hukum positif dan tata moral positif, tetapi ada beda proses pada derogasi dari kedua tata hukum tersebut.

- Pada tertib moral positif, terdapat suatu norma yang hilang keabsahannya karena disebabkan oleh tidak dipatuhinya norma tersebut, atau bisa juga karena munculnya norma lain yang menggantikannya.

- Pada tata hukum positif, setiap norma memiliki keabsahan yang tergantung pada lingkungan waktu dan ruang tertentu

\section{a.Contoh derogasi (1)}

Contoh kasus di Belanda: Larangan pastur katolik untuk menikah merupakan tata moral positif dalam lingkungan masyarakat beragama katolik.

[1] Pada suatu saat tertentu di masa lalu, di Belanda, tata moral tersebut dimasukkan dalam Kitab Undang-Undang oleh legislator: maka dalam lingkungan waktu tertentu dan ruang tertentu diakui sebagai suatu norma dalam tata hukum positif.

[2] Di suatu saat tertentu yang berbeda di masa lalu, legislator di negara Belanda mencabut larangan menikah bagi pastur katolik: maka norma yang mencabut larangan menikah bagi seorang pastur telah menjadi derogasi dan menjadi suatu norma baru dalam tata hukum positif negara Belanda, akibatnya maka makna dalam tata hukum positif berarti 
tidak akan ada lagi seorang pastur katolik yang akan dihukum pidana karena menikah< meskipun pada tata moral positif, aturan tersebut masih diakui keberadaannya oleh lingkungan gereja katolik.

\section{b.Contoh derogasi (2)}

Contoh kasus di Jerman di masa lalu:

[1] Terdapat Norma 1 sebagai berikut "Semua orang yang sudah mencapai usia 21 tahun dan memenuhi syarat kesehatan, harus mengikuti wajib militer".

[2] Terdapat Norma 2 yang berbunyi sebagai berikut "Semua orang yang memenuhi syarat kesehatan, boleh mengikuti dinas militer"

[3] Maka Norma 2 berakibat menjadi derogasi bagi Norma 1 tanpa bermaksud membatalkannya, karrena pada situasi ini dalam Norma 2, tidak terkandung makna keharusan (ought to).

[4] Maka baik Norma 1, maupun Norma 2 bisa dilaksanakan bersamaan tanpa menimbulkan konflik, yaitu setiap orang yang sudah berusia 21 tahun dan memenuhi syarat kesehatan wajib militer, dan setiap orang, tanpa melihat usia, apakah kurang atau lebih dari 21 tahun boleh mendaftar dinas militer.

Pada suatu saat tertentu di negara tsb., minat warga negara sangat besar untuk mengikuti dinas militer, maka hanya ada Norma 2 yang berlaku efektif, dan akan dibuat Norma 3 yang menderogasi Norma 1 yang bisa berbunyi "Terhitung sejak sekarang, sampai waktu yang akan ditentukan kemudian, maka tidak ada lagi wajib militer bagi warga negara". Norma 3 dalam tata hukum positif diakui keberadaannya, tetapi saat bersamaan Norma 1 yang dinyatakan tidak berlaku, tidak serta merta dibatalkan.

Suatu saat tertentu bisa muncul Norma 4 yang berbunyi " Sejak tanggal sekian, Semua orang yang sudah mencapai usia 21 tahun dan memenuhi syarat kesehatan, harus mengikuti wajib militer". Maka Norma 4 adalah tidak lain tidak bukan adalah Norma 1

Tugas : sebutkan satu contoh regulasi di bidang telekomunikasi di Indonesia yang telah mengalami derogasi

\section{Contoh derogasi (3)}

Contoh kasus di USA: Misal terdapat Norma 1: "Semua warga negara boleh mendirikan rumah dan bangunan hanya di atas tanah yang bersertifikat atas nama dirinya". Dan ada Norma 2:"Warga suku Indian yang masih nomaden boleh mendirikan bangunan dan bertempat tinggal di tanah-tanah negara yang tidak bersertifikat pribadi, dimanapun mereka inginkan". Norma 3:"Bolehnya warga Indian nomaden mendirikan bangunan di tanah-tanah negara yang mereka inginkan harus diatur oleh pengadilan di county (kabupaten) masing-masing".

Contoh 3 menjelaskan salah satu fungsi lain dari derogasi, yaitu dalam suatu situasi khusus yang kompleks, dimana legislator melihat diperlukannya 3 buah norma. Norma pertama mengatur bahwa sesuatu $(X)$ harus dilakukan. Norma kedua mengatur bahwa $X$ tersebut TIDAK boleh dilakukan. Dua norma yang berkonflik secara total dan bilateral ditengahi oleh norma ketiga yang menderogasi dua norma pertama dengan cara mengatur bagaimana caranya law-applying organ memilih norma mana yang akan dilaksanakan dari norma 1 dan norma 2 


\subsection{Moralitas dan Hukum}

Di semua Negara di dunia, pernah terjadi konflik antara norma-norma dalam suatu moralitas dan norma-norma dalam sistem hukum. Contohnya, norma sosial yang secara umum tidak tidak diperboleh seorang manusia membunuh orang lain, pada kenyataannya norma hukum yang berlaku sejak ribuan tahun lalu, telah memerintahkan petugas untuk membunuh orang dalam rangka melaksanakan eksekusi hukuman mati yang ditetapkan pengadilan. Karena konflik ini bersifat total dan bilateral, maka pada umumnya setiap negara akan memilih salah satu, apakah akan memenangkan norma sosial atau norma hukum. Jika kita mempelajari sejarah norma hukum di semua Negara di dunia, maka tercatat bahwa di beberapa Negara telah terjadi derogasi berulang kali, suatu saat hukuman mati diperbolehkan, tapi di saat lain ditiadakan, lalu diperbolehkan.

\subsection{Kelemahan Hukum Romawi}

Ajaran hukum Romawi kuno, berdasar prinsip "lex posterior derogat priori" ("hukum yang baru menderogasi hukum sebelumnya") HANYA BOLEH BERLAKU SATU KALI.

Kelemahan prinsip ini, jika ini dipegang teguh, adalah mengabaikan prinsip keberlakuan norma sebagai fungsi ruang dan waktu

\section{Contoh kasus 1}

pemberlakuan norma "pelaku zinah harus dihukum" vs "pelaku zinah tidak harus dihukum".

i. BILA HUKUM ROMAWI BERLAKU: maka di suatu negara yang pernah berlaku norma "pezinah dihukum" lalu pernah diderogasi menjadi "pezinah tidak dihukum", maka di Negara tersebut untuk selamanya berpantang kembali lagi ke norma "pezinah dihukum".

ii. BILA HUKUM RUMAWI KUNO TIDAK BERLAKU: Bisa saja di suatu negara, th 1800 normanya adalah"pezinah dihukum", lalu th 1900, norma hukum diubah menjadi "pezinah tidak dihukum", lalu th 2000 diubah lagi menjadi "pezinah dihukum" dan seterusnya.

\section{Contoh Kasus 2}

Di negara-negara yang usianya masih muda, biasanya prinsip"lex posterior derogat priori" sangat dipegang teguh, sementara di negara-negara yang sudah "tua", prinsip "lex posterior derogat priori" tidak lagi dipegang teguh. Contoh Negara yang "masih muda": ketika reformasi 1998, selama 10 tahun UUD tsb diderogasikan, dimana setelah amandeman Undang-Undang Dasar yang ditulis adalah dalam satu kitab adalah terdiri dari “Pasal-pasal UUD 1945 yang tidak diamandemen"dan "Pasal-pasal UUD 1945 yang diamandemen", disatukan. Prinsip administrasi penyusunan derogasi seperti yang dilakukan menunjukan bahwa tanpa sadar telah menerapkan Hukum Romawi, karena seolah-olah menutup kemungkinan amandeman oleh generasi berikutnya. Seharusnya TEKS UUD 45 DIBIARKAN TETAP SEPERTI APA ADANYA, LALU PASAL-PASAL YANG DIAMANDEMEN DITULIS TERPISAH DALAM KITAB AMANDEMEN UUD YANG DILENGKAPI DENGAN TANGGAL DIBERLAKUKANNYA, Dengan demikian, jika suatu saat dilakukan amandemen lagi, misalkan suatu pasal UUD 1945 yang pernah diamandemen, oleh generasi mendatang dinyatakan berlaku lagi, maka tinggal dituliskan suatu pasal amandemen secara terpisah suatu kalimat pendek "pasal sekian UUD 1945 dinyatakan berlaku lagi". 


\subsection{Analogi yang menyesatkan}

Dalam ilmu logika secara umum, analogi adalah sah untuk dilakukan, tetapi ada banyak kasus dimana analogi ternyata bisa menyesatkan. Di sisi lain, analogi sering dilakukan oleh masyarakat awam, yang selalu dianggap benar tanpa mempertimbangkan bahwa proses analogi yang dilakukan ternyata kurang tepat, sehingga telah menyesatkan.

Mayoritas ahli hukum di dunia berpendapat bahwa analogi tidak patut diberlakukan dalam bidang hukum. Ernst Mach, dalam bukunya Erkenntnis and Irrtum, eds.4. 1920. p.225, mengatakan bahwa argumen analogikal bukan merupakan unsur logika, hanya sesuai untuk ilmu psikologi, dan menjadi problem bagi ilmu hukum. Dia mencontohkan, dalam paragraph 49 b. Paragraph III dari Kitab Undang Undang Hukum Pidana Belanda, disebutkan "bahwa setiap orang yang terlibat dalam persengkokolan untuk membunuh orang, tetapi pada saat yang tepat telah memberitahu kepada pihak berwajib atau calon korban, sehingga dimungkinkan mencegah terjadinya kejahatan tidak akan dihukum". Pendapat yang sama disampaikan oleh Ulrich Klug dalam bukunya Juristische Logik, cet. 2, 1958, p.125, yang mencontohkan paragraph 433 dari Kitab Undang-Undang Hukum Sipil Jerman, yang berisi peraturan tentang penyerahan hak milik benda berwujud secara kontraktual, telah diterapkan dengan jalan analogi pada penyerahan secara kontraktual atas usaha-usaha komersial secara umum, termasuk goodwill. Padahal Ulrich Klug berpendapat bahwa kedua hal tersebut jelas-jelas berbeda

\section{Contoh analogi yang menyesatkan (1):}

Kasus di Amerika: Berdasar norma "semua koruptor harus dihukum" maka "Smith harus dihukum" bila "Smith telah melakukan korupsi". Tetapi norma "semua koruptor harus dihukum" ternyata mungkinberkonflik dengan norma lain yaitu "koruptor dalam lingkungan keluarga sendiri diselesaikan secara kekeluargaan dan tidak dihukum oleh pengadilan". Dengan demikian bila ada kasus, sebagai contoh, Smith telah menggunakan uang keluarga yang menurut keputusan keluarga harusnya digunakan untuk membeli mobil, ternyata digunakan oleh Smith untuk membeli rumah, ketika pihak keluarga mengajukan Smith ke pengadilan atas tuduhan korupsi, maka hakim-hakim mempunyai pilihan apakah akan menghukum Smith atau tidak. Satu hakim mungkin saja berbeda pendapat dengan hakim lain, dan bahkan satu hakim yang sama suatu saat memutuskan menghukum "koruptor" semacam Smith tadi, di saat lain memutuskan membebaskan Smith

\section{Contoh Analogi yang menyesatkan (2)}

Contoh di Indonesia: Masyarakat akan "menghakimi" seorang hakim yang membuat keputusan berbeda atas dua kasus berbeda, misal kasus A dan kasus B, yang oleh masyarakat dianggap sebagai kasus yang sama atau mirip. Dalam hal ini, masyarakat merasa benar, karena melalui proses analogi yang dilakukannya telah menghasilkan kesimpulan "kasus A adalah sama dengan kasus B", sementara di pihak lain, hakim yang memutuskan kasus $A$ dan $B$ dengan mengacu rinciannya fakta yang terungkap di pengadilan, dan tidak melakukan proses analogi, adalah sangat yakin bahwa kasus $A$ adalah tidak sama dengan kasus $B$

\subsection{Logika Yuridikal}

Para ahli hukum di dunia masih berbeda pendapat tentang apakah ilmu hukum sebenarnya berdasar ilmu logika secara umum, ataukah berdasar ilmu logika khusus yang disebut logika yuridikal. Keyakinan mayoritas saat ini adalah, yang membedakan ilmu hukum dengan ilmu psikologi adalah: ilmu hukum tidak menganggap bahwa argumen analogikal adalah TERMASUK dalam ilmu logika. Dalil- 
dalil hukum (legal theses) dibentuk dan ditetapkan berdasar operasi-operasi logikal tertentu. Ilmu logika umum diterapkan pada proposisi-proposisi deskriptif dari ilmu hukum pada norma-norma preskriptif dan hukum adalah persis sama dengan yang diterapkan dalam ilmu \& teknologi lainnya

\subsection{Prinsip prinsip Hukum Islam}

Hukum Islam, ilmu fiqih menjadi salah satu bidang kajian di Negara-negara barat, dan telah memasukkanya menjadi pertimbangan penyusunan norma hukum

Hukum Islam mempersyaratkan bah suatu norma harus mengacu pada lima syarat tercapainya tujuan penciptaan manusia oleh Allah, sesuai yang ditulis di Quran:

- Ketentuan Tuhan seperti yang terkandung dalam Al Quran adalah SELALU dapat diketahui dan dimengerti oleh manusia, jika suatu ayat tidak bisa dimngerti, maka dinyatakan sebagai "belum bisa dimngerti saat ini".

- Manusia harus mau dan mampu bertindak untuk mengaktualisasi ketentuan Tuhan

- Alam dan ciptaan Tuhan dapat diubah melalui perbuatan manusia

- Harus ada penilaian bahwa suatu perbuatan manusia bukan merupakan perbuatan sia-sia

- Perbuatan manusia harus dilakukan berdasarkan neraca keadilan

\section{Sifat syariat Islam:}

Hukum Islam terdiri dari dua jenis:

- Hukum yang tidak dapat diubah mencakup hukum preskriptif (maqadir) Al Quran dan Sunnah, keduanya terikat oleh teksnya.

- Hukum yang dapat diubah, karena tekstualnya tidak terdapat di Quran.

\section{$>$ Proses penentuan hukum Islam:}

Proses penentuan suatu norma akan berlaku menjadi hukum islam

- Ijma': adalah kesepakatan antara orang-orang yang dikalangan umat Islam dipandang sebagai ahli ilmu hukum Islam atau fakih

- Qiyas: penempatan suatu masalah baru di bawah hukum Islam yang sudah ada berdasar prinsip ekivalensi, yang dilakukan untuk suatu masalah baru, dimana para fakih tidak bisa melakukan ijma

$>$ Ushul al-figh: adalah suatu ilmu untuk mensistematisasikan perkembangan hukum untuk menghadapi situasi dan problem baru, dan untuk melembagakan penyesuaiannya secara kontinu terhadap hukum Islam.

\section{$>$ TUJUH prinsip Ushul al-figh:}

- At tammassuk bil-ashl: bahwa segala hal yang bermanfaat adalah absah dan yang membawa mudarat adalah tidak absah 
- Istishshab bil al-hal: Suatu hukum dinyatakan akan tetap berlaku sampai dengan ada yang mempertanyakan hakekat manfaatnya

- Al-mashalih al-mursalah: manfaat dipandang absah jika diketahui bahwa syariat telah memapankannya

- Adh-dhara'i: keabsahan suatu hukum dipengaruhi oleh manfaat atau mudharat yang tersirat dalam tujuan akhirnya

- Al-istiqra' an-naqish: suatu hukum yang bersifat umum (universal) dapat diturunkan dari hukum khusus (partikular) melalui generalisasi, kecuali ada yang mempertanyakan generalisasi tersebut

- Al-istihshan: qiyas yang lebih lemah boleh didahulukan dibanding qiyas yang lebih kuat jika ia lebih memenuhi tujuan umum syariat

- Al-'urf wal-'adah: adat dan praktek perbuatan yang mapan di suatu daerah dapat menjadi sumber hukum yang absah

\subsection{Soal-soal}

1. Sebutkan satu contoh hukum positif dan satu contoh hukum normative pada sector telekomunikasi

2. Sebutkan law applying organ dalam sector telekomunikasi di Indonesia

3. Sebutkan lembaga yang mempunyai yudicial discretion pada sector telekomunikasi di Indonesia

4. Sebutkan norma-norma dalam sector telekomunikasi di Indonesia yang memiliki:

(a)konflik bilateral, (b)Konflik parsial dan bilateral, (c)Konflik parsial dan unilateral

5. Berilah contoh norma dalam sector telekomunikasi yang telah mengalami derogasi berulang ulang

6. Lakukan uji silogisme praktikal untuk membuktikan bahwa: (a)Suatu imperatif dalam bidang telekomunikasi DAPAT menjadi suatu norma hukum; dan (b) (a)Suatu imperatif dalam bidang telekomunikasi TIDAK DAPAT menjadi suatu norma hukum;

7. Examples of a derogation on telecommunications regulation in Indonesia, download:

“KEPUTUSAN MENTERI KOMUNIKASI DAN INFORMATIKA REPUBLIK INDONESIA NO 51/KEP/M.KOMINFO/01/2012"

in the link: http://www.postel.go.id/regulasi-keputusan-menteri-39

Answer the following questions:

a. What is the primary consideration of the Ministerial Decree (KM) of the Communications and Information Technology

b. Read the Kominfo KM Title of article 1: Write the number of the first KM Kominfo (prior to amendment), and then specify second KM Kominfo = first 
changes; and specify the number of the 3rd KM Kominfo = the second change and specify the number of the fourth KM Kominfo = third amendment (if any).

c. Analyze, what exactly has been corrected by the government

d. Write shorter sentences, but more sense, to replace the existing sentence of article 1

\section{Post Test 2 - ET 4040 Semester 2 tahun 2017/2018 = soal UTS semester 2 tahun 2017/2018}

1. Sebutkan satu contoh hukum positif dan satu contoh hukum normative pada sector telekomunikasi

5. Sebutkan contoh 3 law applying organ dalam sector telekomunikasi di Indonesia

6. Sebutkan contoh 3 lembaga yang mempunyai yudicial discretion pada sector telekomunikasi di Indonesia

7. Gunakan teori silogisme praktikal untuk membuktikan apakah imperative berikut dapat dijadikan norma hukum atau tidak "Semua operator seluler harus membayar BHP (Biaya Penggunaan Pemakaian) spectrum ftrekuensi ".

8. Analisa apakah dua norma hukum TV broadcast di Indonesia ini mempunyai konflik atau tidak, jika ada sebutkan jenis konfliknya: Regulasi 1: "Saat ini setiap Content Provider broadcast TV analog (TVRI, RCTI, MetroTV, TVone dll ada sekitar 20 content provider per wilayah siaran) diberikan hak menggunakan spectrum tersendiri@1 kanal tv analog per Content Provider per wilayah siaran" dan regulasi 2:" Pada TV broadcast digital yang menggunakan teknologi DVB-T2, setiap operator multplekser DVB-T2 diberian hak menggunakan 1 kanal TV di setiap wilayah siaran dan wajib menyiarkan 9 content provider TV".

\section{DAFTAR PUSTAKA}

[1] Hans Kelsen. (1973). Essays in Legal and Moral Philosophy. PublishingCompany, Dordrecht, Holland.

[2] Isma'il Al-Faruqi. (1986). The Cultural Atlas of Islam. Macmillan Publishing Company. New York, USA.

[3] Sigit Haryadi. (March 2017). Catatan Kuliah "Overview Organisasi Regulasi Telekomunikasi". Researchgate, DOI10.13140/RG.2.2.34928.05122. Retrieved from: https://www.researchgate.net/publication/314939825_Catatan_Kuliah_Overview_Org anisasi_Regulasi_Telekomunikasi

[4] Sigit Haryadi. (March 2017). Catatan Kuliah Lisensi Provider dan Operator Telekomunikasi. Researchgate, DOI10.13140/RG.2.2.13117.67046. Retrieved from: https://www.researchgate.net/publication/314938861_Catatan_Kuliah_Lisensi_Provid er_dan_Operator_Telekomunikasi

[5] Sigit Haryadi. (January 2017). Ekonomi Bisnis Regulasi dan Kebijakan Telekomunikasi: Prinsip-Prinsip Ilmu Hukum. Researchgate, DOI10.13140/RG.2.2.30524.03207. Retrieved from: https://www.researchgate.net/publication/313159546_Ekonomi_Bisnis_Regulasi_dan _Kebijakan_Telekomunikasi_Prinsip-Prinsip_Ilmu_Hukum 